\title{
Analysis of The Legal Thought of Postmodern Era of The Development Legal Theory By Mochtar Kusumaatmadja and Progressive Legal Theory By Satjipto Rahardjo For Legal Development of Indonesia In The Perspective of ontological, Epistemological And Axiological
}

\author{
Munnie Yasmin \\ The Law Faculty, Udayana University, Bali, Indonesia
}

\begin{abstract}
Formulating law derived from the value of the entire people of Indonesia is related to the law which is responsive, which is able to accommodate the desire of all the people of Indonesia. Development of national legal system is implemented on three elements i.e. the substance, structure and legal culture. Development of law against the order of the three elements can be done by means of law renewal. Renewal of the law can be improve what already exists or create something new. The second alternative ways, making something new is something to change the old thinking. Distrust on the reliability will realize new thing. This thought is the core of postmodern ideology thought. Postmodern ideology has been influential in the formation of positive law in Indonesia. Legal theories produced by Indonesian thinkers are required for the development of national laws in accordance with the condition and the situation of Indonesian society by using the reference frame the view Indonesian nation based on the kinship system. Thought of postmodern legal theory derived from the Indonesian nation i.e. the development legal theory by Mochtar Kusumaatmadja and progressive legal theory by Satjipto Rahardjo. Based on this perspective needs to be analyzed in the perspective of ontological, epistemological and axiological both the legal theory that can be applied in the development of law in Indonesia.
\end{abstract}

Keywords: postmodern legal theory, legal development, law renewal, development legal theory, progressive legal theory

\section{Background}

\section{INTRODUCTION}

Law is an integral part of community life. Law regulates people's behavior. A Roman philosopher Cicero approximately 19 centuries ago the famous revealed ubi societas ibi ius that means if there's a society, law will be there. The society needs the rule of law so that life becomes orderly.

Law is born from a social dimension which aims to create orderliness, security and social justice for all Indonesian people. Formulated the law derived from the value of all the people of Indonesia is on the question of how the law creating the responsiveness that is able to accommodate the wishes of all the people of Indonesia. In fact, the phenomenon of law enforcement in Indonesia leaves a sense of deep concern because of the lack of reflection for justice and conscience of the Indonesian people.

The phenomenon of poor law enforcement have been indirectly affected by the normative legal doctrine that comes from the school of positivism by just looking at the law as written norms and a close eye on social phenomena that exist. Problems arise if the law faced with the community dynamics that continue to grow and develop so that the law is not capable of resolving the problems that occur in the community. The law will be left behind whereas a good law is the responsive law.

The legal condition above requires a settlement by presenting theories of law in accordance with the conditions and the situation of Indonesian society. Development of national law is needed so that current law could be better and able to emerge as a representative of the aspiration and soul of the people of Indonesia. Development of national law as a system will not be rid of the three elements as proposed by Lawrence Friedman i.e. the substance, structure, and culture. The substance of the legislation, the procurement organizational structure and its enforcement, and culture of the community and law enforcement will be intertwined for the successful development of national laws.Achmad Ali ${ }^{1}$ outlines the opinion of Lawrence M. Friedman about the three elements forming a legal system. His explanation outlines that the substance is the

${ }^{1}$ Achmad Ali, 2009, Menguak Teori Hukum (Legal Theory) dan Teori Peradilan (Judicial Prudence) Termasuk Interprestasi Undang-Undang (Legisprudence), Kencana Media Group, Jakarta, h.226. 
overall rule of law (including the principle of law and legal norm) both written and unwritten including adjudication. The structure is the overall legal institutions and their staff members so including the police force with its police, office of the counsel for the prosecution with its prosecutors, the court with its judge. Legal culture that is defined as ideas, attitudes, beliefs, expectations and opinions about the law.

Development of the national legal system lain in order to three elements can be done by means of law renewal. Renewal of the law can be improve what already exists or create something new. The second way to make something new that is something to change the old thought. Distrust on the reliability will realize new thing. This thinking is the core of postmodern ideology thought. Postmodern ideology has been influential in the formation of positive law in Indonesia. The influence of National figures thought in the postmodern era will look at the progress and development of law in Indonesia on the philosophy of law and principles of law that are fundamental in accordance with the values, norms and behavior as well as the nation of Indonesia based on Pancasila. Legal theories produced by Indonesian thinkers are required for the development of national laws in accordance with the conditions and the situation of Indonesian society by using the reference frame of the view Indonesian nation based on the kinship system including three elements of Friedman namely the substance, structure and legal culture. National figures who have had a role to contribute his thoughts on the law, among others Mochtar Kusumaatmadja with development legal theory and Satjipto Rahardjo with progressive legal theory.

\section{Problem Formulation}

Based on the description so that the subject of study in this paper, the point of the problem is how the analysis of postmodern legal theory thought i.e. development legal theory by Mochtar Kusumaatmadja and progressive legal theory by Satjipto Rahardjo for legal development of Indonesia in the perspective of the ontological, epistemological and axiological?

\section{DISCUSSION}

Analysis of the development legal theory and the progressive legal theory viewed from the perspective of ontological, epistemological and axiological is explained by describing in advance about the cores thought of development legal theory and progressive legal theory.

1. Development Legal Theory By Mochtar Kusumaatmadja

According Lilik Mulyadi that the development legal theory by Mochtar Kusumaatmadja needs to be studied with a number of considerations such as:

a) The theory of Development Legal up to now is a legal theory that still exist in Indonesia because it was created by the people of Indonesia to see the dimensions and culture of Indonesian society.

b) The theory of Development Legal uses reference views of community life as well as the Indonesian nation based on the principles of Pancasila which is the kinship system to the norms, principles, institutions and rules contained in the theory of development legal has included the substance, structure and culture in accordance with the theory of Lawrence M. Friedman .

c) The theory of Development Legal provides a basis function of the law as a means of renewal of society and the law as a system that is needed by a nation of Indonesia as a developing country.

d) The theory of Development Legal provides a basis function of the law as a means of renewal of society and the law as a system that is needed by a nation of Indonesia as a developing country. ${ }^{2}$

Mochtar Kusumaatmadja views that the ultimate goal and first of all the law is order, which is a fundamental condition for the existence of an ordered society. ${ }^{3}$ Lilik Mulyadi quoted Mochtar that:

Law is a tool to maintain order in society. In view of its functions, the legal characteristic, basically is a conservative, meaning legal measures up to nurturing and sustaining that have achieved. That function is needed in every community, including the people who are building, because there are the results that should be preserved, protected and secured. But then, people who are building, which in our definition means rapidly changing society, the law does not quite have such functions only. It must also be able to assist the process of change in society. The views are conservative on law which emphasizes the maintenance of order in the sense

${ }^{2}$ Lilik Mulyadi, 2008, Teori Hukum Pembangunan Prof. Dr. Mochtar Kusumaatmadja S.H.,LL.M. Sebuah Kajian Deskriptif Analitis, Sumber http://www. badilum.info/ images/ stories/artikel/ kajian_deskriptif_analisa_teori_hukum_pembangunan.pdf, diakses pada tanggal 14 Desember 2014, h.1-2.

${ }^{3}$ Shidarta, 2012, "Posisi Pemikiran Teori Hukum Pembangunan Dalam Konfigurasi Aliran Pemikiran Hukum (Sebuah Diagnosis Awal)" dalam : Shidarta (ed): Mochtar Kusuma-Atmadja dan Teori Hukum Pembangunan Eskistensi dan Implikasi, Epistema Institute, Jakarta (selanjutnya disebut Shidarta I),h.32. 
of function static, and emphasizes the conservative nature of the law, assume that the law can not play a significant role in the renewal process. ${ }^{4}$

In connection with the function of the law presented, Mochtar gives a definition of law in a broader sense not only including the overall principles and rules governing human life but also the institutions and processes that embody the enactment the rules in reality. The four components basis, rule, institutions and processes are integral cooperate to realize the objectives of the law.

Lili Rasjidi and I.B. Wyasa Putra ${ }^{5}$ illustrate the interconnectedness of the theory of development legal with different ideas of other legal theories. The theory of development legal is the result of the sum of the legal theory of Mochtar with the legal theory of Pound, adjusted to the conditions in Indonesia. Especially for the legal theory of Mochtar, the formulation was formed by means of Northrop cultural theory "Policy Oriented" Lasswell-McDougal. The legal theory of Pound is also no longer appear as the original models, but has been reduced the mechanical conception by Mochtar.

The theory of development Legal is a legal concept modified and adapted from Roscoe Pound's theory "law as a tool of social engineering" (minus the mechanical conception) and is influenced by the thought of Herold D.Laswell and Myres S.Mc Dougal (Policy Approach) turned by Mochtar Kusumaatmadja and adapted to the conditions in Indonesia. ${ }^{6}$ The theory presented Laswell and Mc.Dougal that the importance of the cooperation between the carrier of theoretical law and researcher in general and bearer of practical law in process engender a public policy associated with Mochtar's theory that involves the entire stakeholders in the social community. ${ }^{\top}$

The collaboration process is added to the pragmatic purposes (for development) in accordance with the theory of Roscoe Pound and Eugen Ehrlich correlation menu between Laswell and Mc.Douglas statement that the cooperation between the researcher of the law and the carrier of practical law are ideally able to bring legal theory (theory of law), theory which has a pragmatic dimension or practical utility. Mochtar changes the definitian of law as a tool (tool) into law as a means (instrument) for community development.

The basis of thought for the law as a tool for community development that the law in the sense of norm is expected to steer human activity to the desired direction by the development and renewal. Mochtar argued that the law as a means of understanding broader than the law as a tool, because:

a) In Indonesian statutory role in the process of legal reform is more prominent, for example, compared with the United States that put the jurisprudence (in particular the decision of the Supreme Court) on the more important place.

b) The concept of law as a "tool" will lead to results that are not much different from the application "legisme" as held at the time of the Dutch East Indies. And In Indonesia, there is the attitude of the people who show sensitivity to reject the application of the concept.

c) If the "law" here as well as international law, the concept of law as a means of society renewal have already applied long before this concept was formally accepted as the basis of national law policy. ${ }^{8}$

Shidarta suggests the cores of development theory of Mochtar Kusumaatmadja. These are':

a) good rule is a rule that reflects the aspirations and soul of the community, the social norm consists of moral, religious, morality, courtesy, customs, and laws, so that a good law is in accordance with the laws of life (living law).

b) Institutions and processes in applying the law in reality, is one of the elements in addition to a set of rules and principles.

c) The sanction is required as a means of coercion rule of law in the society by the state through the tools of equipment, law not the rule of instigation, and power as a means to order the society, but power is not without limits.

d) One of the conditions applying to effective power if it gets the support of the party which is subjected to the power, so in order to get the support it needed the tradeoffs between ruler and ruled. Which ruler eager devotion to the public interest (sense of public service), and which ruled has the duty of. the law-abiding (the duty of civil obedience), which are aimed to the public interest (public service).

\footnotetext{
${ }^{4}$ Lilik Mulyadi, Op.Cit, h.3-4

${ }^{5}$ Lili Rasjidi dan I.B. Wyasa Putra, 1993, Hukum sebagai Suatu Sistem, Remaja Rosdakarya, Bandung, h.126.

${ }^{6}$ Shidarta, 2006, Karakteristik Penalaran Hukum Dalam Konteks Keindonesiaan, CV.Utomo, Jakarta (selanjutnya disebut Shidarta II), h.411.

${ }^{7}$ Lilik Mulyadi, Op.Cit, h.2-3.

${ }^{8}$ Shidarta II, Op.Cit, h.414-415.

${ }^{9}$ Shidarta I, Op.Cit, h.19-22. 
e) Justice ranks last after certainty, and order. Order was the first purpose of the rule of law so that it can achieve its main objective that is regularity society. Certainty is needed to achieve order, and Justice in the final sequence because justice may vary depending on the community and his contemporaries.

f) Renewal the way of thinking (attitudes, characteristics and values) in Indonesian society in this regard rulers and ruled, is needed because Indonesia is in transition between way of the ancient thinking (closed) to the way of modern thinking (open, dynamic, forward) so it is expected that every Indonesian citizen is able to remain active in the implementation of their rights.

g)The law functioned mainly as a means of manipulating the public for the Indonesian people who are building rather than a legal function that is conservative (preserving and maintaining the status quo), with priority order for the changes to be running well.

h) Development of a holistic and comprehensive manner not only from an economic standpoint, but also all sides of public life.

i) The negative impact of the adoption of the law as a means of renewal of society is overcome by implementing carefully with studying and involving a spectrum of sciences outside the law such as sociology, anthropology and culture. Hukum as a means of renewal in communities that are building it can also be detrimental, so it must be done carefully.

j) The main emphasis in the legislative process as a tool of the most logical and effective is compared to the jurisprudence and the common law so that the function of the law to ensure the change in an orderly way can be met.

k) The obstacles faced by law in the development can be divided into two: objective and subjective. The objective obstacle including: (a) the determination of interest of law reform; (b) the availability of empirical data that is lacking in doing explanation and prediction (c) the difficulties in determining the success of legal reform measure objectively. Subjective obstacle including: (a) the disagreement with the characteristic of charismatic leadership between the ideals of law reforms towards a state of law; (b) the lack of legal authority in the view of society (respect for law), especially for the post-revolution society ; (c) the view that the changes shake the honor; (d) attitude of an assessment of the incompatibility toward behaviors intellectuals in practicing on values or traits they suggest; pluralistic of Indonesian society.

1) The establishment of laws is directed at sectors that are not as sensitive as customs, religions and values so that avoid controversy and conflict. In order to establish law in the era of Indonesia that is building, needs to prioritize the establishment of legislation in the fields neutral law (not sensitive). The realm of law is practical, will not cause a lot of controversy associated with customs, religion, and values that most other basis.

Based on this core of development legal theory seems that there is a balance between positive law with the live law. The function of law that leads to renewal means, but still uphold and prioritize the value of order as a condition for the emergence of justice and legal certainty. Law live and develop in line with the development of society, is the thought that goes along with the ideology of sociological jurisprudence, namely the development of society which is only found in the judgment on the assumption that the judgments contain the values of truth recognized the society in which the law is alive and growing. The thought is in line with the thought from Savigny stating that the law always left behind the development of the communities with the ideology of history.

The difference with the ideology of sociological jurisprudence, theory of development legal focuses on the community change by means of legislation. In the Indonesia legal system, laws become the main source of law not jurisprudence. ${ }^{10}$ Mochtar $^{11}$ stated that "Strengthening the principles of the law in the firstly can be done to effort the establishment of national law through (process) legislation (legislation). In the implementation stage those principles to be established through judicial decisions. "Every law is a product of politics can not be separated from the interests of influence of power that will affect the value of justice. That will have an impact under the law makers as a "motor" in moving the functions of the law.

\section{Progressive Legal Theory By Satjipto Raharjo}

Progressive legal theory begins with dissatisfaction function of law in realizing a better life in Indonesia. Progressive legal theory emphasizes the correction of the law by way of re-thinking of the way to learn and how to arbitrate which aims to bring true justice and substantive justice.

\footnotetext{
${ }^{10}$ Berdasarkan Undang-Undang Republik Indonesia Nomor 12 Tahun 2011 Tentang Pembentukan Peraturan Perundang-undangan tidak memasukkan yurisprudensi sebagai sumber hukum.

${ }^{11}$ Mochtar Kusumaatmadja, 1997, "Pemantapan Cita Hukum dan Asas-Asas Hukum Nasional Di Masa Kini dan Masa Yang Akan Datang”, Majalah Hukum Pro Justitia Nomor 2 Tahun XV, April 1997, h.14. 
Progressive legal theory was born from disappointment to law enforcement that often positivist perspective, ie just focus on the text in the law without going to explore the values of justice deeper. Rule breaking is one of the strategies in this theory to solve the problem positivist and a deadlock in legislation and proceedings (this is in accordance with the spirit of postmodern ideology).

Satjipto Rahardjo distinguished characteristic, function and role of law in development into two things: ${ }^{12}$

a) The law is always placed to seek the foundation of endorsement of an action to uphold the procedural characteristics of the legal basic and regulatory basis.

b) The law in development is instrumental character that has been considered to undergone exchanges with the power outside the law so that the law becomes a channel for running a political decision or the law as a tool of social engineers, namely:

1)The law is intended to strengthen and secure the implementation of development and its results.

2)Legal gives support and direction to efforts to achieve a fair and equitable prosperity.

3)Legal grows and develops the moral discipline and a sense of social responsibility to every member of society.

4)The law creates a climate and environment that encourages creativity and community participation in development and support of national stability dynamic and sound.

Satjipto Raharjo stresses that progressive laws proceeding from the assumption of the legal basis for man and not vice versa. The law can not be accepted as an institution that is final and absolute. Explicitly formulated that progressive law is a correction to the modern of bureaucratic law and is rid of itself from the domination of the type of liberal law. The type of liberal law is criticized by Satjipto as a tool for the workings of capitalism. Law serves only to justice and not the rule.

According Satjipto Raharjo ${ }^{13}$ that entered the $20^{\text {th }}$ century and early $21^{\text {st }}$ century there is an important resistance to the domination of state power. The hegemonal characteristic of state is restricted and begin to appear recognition of the pluralism of society, the state is no longer absolute power. Local wisdom appeared, and raised awareness that the state is not the only truth This is a picture of the transformation of legal experiencing bifurcation (branching) from the legal patterns that have character formalism, rational and resting on procedures, shifts in thought that emphasizes the substantial justice. Understanding bifurcation or branching between formal justice with substantive justice is described by Satjipto Rahardjo as quoted by Otje Salman and Anthon F. Susanto that ${ }^{14}$ :

This is where modern laws are at a intersection because between justice that has been the cut-off and the law has been applied there is the large differences. Territory justice is not exactly the same as the area of positive law. The dire circumstances appear conspicuously when we talk about the "supremacy of law". What do we mean? Supremacy of justice or supremacy of law? The intersection circumstances also appear to interpretation such as "formal justice" or "legal justice" on one side and "substantial justice" on the other.

Departing from the idea Satjipto Rahardjo that the law does not exist for itself but for the people and communities that carry the law out can not be equated with spelling article of law mathematically, so except the logic, also needed philosophical foundation and social ${ }^{15}$. The three of things i.e. legal logic, philosophical logic and social logic will always have a different portion.

The different portion among legal logic, philosophical, and social are affected due to the demands of justice and expediency. Legal certainty implicitly followed the law will only be useful for the law itself, but not to the public. Satjipto Rahardjo agrees with the statement of Karl Renner that the law change not only in the sector of formal (changes at the formal text/regulations) but also can occur when a substance that regulated has experienced changes of the legal and trying to keep up with entering the legal expediency factor. ${ }^{16}$

In addition to support the opinion of Renner, Satjipto Rahardjo also supports the idea of justices Oliver Wendell Holmes who said that "The life of the law has not been logic, but experince"17. Based on the opinion, the Holmes have incorporated elements of behavior into the law that influence the thought of Satjipto Rahardjo.

\footnotetext{
${ }^{12}$ Satjipto Rahardjo, 2009, Hukum Progresif : Sebuah Sintesa Hukum Indonesia, Genta Publishing, Yogyakarta (selajutnya disebut Sajtipto Rahardjo I), h.1-9.

${ }^{13}$ Turiman, 2010, "Memahami Hukum Progresif Prof Satjipto Rahardjo Dalam Paradigma Thawaf (Sebuah Kontemplasi Bagaimana Mewujudkan Teori Hukum Yang Membumi/Grounded Theory MengIndonesia)", Artikel, sumber: www.acadamia.edu, diakses pada tanggal 20 November 2013.

${ }^{14}$ Otje Salman dan Anthon F.Susanto, 2010, Teori Hukum Mengingat, Mengumpulkan, dan Membuka Kembali, Refika Aditama, Bandung, h.147.

${ }^{15}$ Satjipto Rahardjo, 2008, Biarkan Hukum Mengalir Catatan Kritis tentang Pergulatan Manusia dan Hukum, Buku Kompas, Jakarta (selanjutnya disebut Satjipto Rahardjo II), h.87.

${ }^{16}$ Ibid, h.89.

${ }^{17}$ Ibid, h.90. 
Satjipto Raharjo states that the progressive legal adheres the ideology: pro-justice law and pro-people law. ${ }^{18}$ Based on this ideology, the dedication of the perpetrators of law gets the main place for the restoration, changes by doing a creative meaning to the existing regulations, without waiting for regulatory changing (changing the law). Progressive legal theory of Raharjo Satjipto that adheres the ideology of pro-justice law and pro-people in the context of legal justice in Indonesia is based on Pancasila ideology, is not universal, make change to the creative meaning of the existing rules, as one of the characteristics of postmodern legal theory.

Shidarta summarizes the views of progressive legal theory of Satjipto Rahardjo by presenting some of the core mind, namely ${ }^{19}$ :

a) People have higher social status than the law. The progressive law is for man, not man for the law. The law is a tool for mercy for the world and humanity. Law is not intended for itself, but for humanity. If there is a problem in the law, then thelaw is fixed, not human.

b) People are served by law. Justice is above the rules. The Progressive legal should be pro-people and projustice. The law should be siding with the people. The Dexterity of law enforcement in dealing with stiffness regulatory text (termed "mobilization law") if the rule of law injured sense of people justice. The size of the principle of pro-people and pro-justice to avoid progressivism is not misused.

c) Welfare and happiness is the goal of progressive law.

d) The ability of law in serving the human characterize the institution of law is not final. Progressive law is always in the process of being towards completing better (law as a process, law in the making). Each decision making stages for better decision (executive, legislative and judicial). Law is always influenced by the power of society in regulating order to itself. Societal power buried at certain moments will arise and resolve what can not be solved properly by state law, so the ideal law is allowed to flow.

e) The law is based on human behavior. A legal system would be good if the behavior (in particular law enforcement) is good. There is a relationship between the behavior with the law, the better behavior to the better the law, either vice versa. The progressive law emphasizes the good life as legal basis good.

f) The law is directed at objectives that are more flexible outside the context of the narrative text of the law. Progressive law has responsive type. Nonek and Selznik calledit it as "the souverignity of purpose", which criticized the autonomous law can not be bothered and is final.

g) The power of the community has a role in helping the law to achieve its objectives. Law has limited capacity, can not resolve all the problems based on the strength of its own laws, but instead require a public role as an independent power in defending itself that while this is under the shadows of the state law. in order to the progressive law encourages public role.

h) The main substance of the law is the culture. The culture of happiness people which can be achieved by prioritizing "a state with conscience" (state of conscience) rather than "the legal structure of the state" (the legal structure of the country). The progressive Legal builds a law state with conscience. State for the happiness of the people.

i) The aspect of the inner intelligence as a tool to run a progressive law. The inner intelligence/spiritual is not fixated on the context but it can cross border to seek a deeper truth.

j) The progressive legal does not satisfied to establishment. The progressive legal braves to make changes and reject the the absoluteness because absoluteness would be contrary to the function of the law to the people. The character of Progressive law Is to subvert, change and release.

Satjipto Rahardjo regards that legal rests on the regulatory aspects and behavior (rules and behavior). Regulation would establish a system of positive legal that is logical and rational. While aspects of behavior or human will set a going of regulations and systems that have been constructed. Because the assumption is constructed here, that the law can be seen on the social behavior of the law enforcement and the community. Satjipto Rahardjo put the behavioral aspect above of regulatory aspect, thus the human factor and humanity have an important role in the enforcement and implementation of the law.

Giving priority to behavioral factors (human) and humanity ahead of regulatory factors, means to shift the mindset, attitudes and behavior of legalistic-positivistic to humanity as a whole (holistic), the human as an individual (individual) and human being. In such a context, every human being has the responsibility of individual and social responsibility to provide justice to anyone.

3. Analysis of Development Legal Theory and Progressive Legal Theory in perspective of Ontological, epistemological, and axiological

\footnotetext{
${ }^{18}$ Satjito Rahardjo I, Op.Cit, hal.190.

${ }^{19}$ Shidarta, Posisi Pemikiran Hukum Progresif Dalam Konfigurasi Aliran-Aliran Filsafat Hukum (Sebuah Diagnosis Awal), sumber http: www.slideshare.net, diakses pada tanggal 14 Desember 2014, h.3-5.

DOI: $10.9790 / 0837-2109026675 \quad$ www.iosrjournals.org $\quad 71 \mid$ Page
}


Based on the explanation above it appears that the legal theory of development was born and motivated because of the assumption that the law can not contribute even impede a change in society and in the the reality of community in Indonesia there has been a shift in thought towards the modern law. The same reason is the anxiety of Satjipto Rahardjo to the development of legal in Indonesia due to no operation of law as a system of behavior. The emergence of these two theories because the law is considered unenforceable or fulfilled properly so expected the change to the contribution of thought produced the national figures.

Ontologically development legal theory views the law as a system of norms (system of norms) so rely on the normative power of the law to change attitudes and behavior. Progressive legal theory emphasizes law as the behavior of the system (system of behavior) as a means to human happiness. The progressive legal theory recognizes the existence of the law as a political product but it exists to serve humans, if problems arise in the enforcement so the law should be improved, not human.

Epistemologically, the development legal theory use approach of nondoctrinal-deductive and doctrinalinductive simultaneously followed doctrinal-deductive, meaning the first approach remains the law is determined by the legislative body to be applied in the community, and the results of the evaluation process (feedback) from the social reality that occurs will stimulate new legislative program, either the formation of a new positive norms, the revocation of positive norms old, or change $\mathrm{e}^{20}$.

The development Legal theory focuses on the changes in the realm of the neutral legal (not sensitive). The realm of practical legal will not cause a lot of controversy associated with customs, religion, and other primordial values. The realm of the neutral legal here is emphasized on the legal realm of economic viewed on the development of the new order that is being focused on economic development.

Epistemologically, progressive legal theory uses approach nondoctrinal-inductive and doctrinaldeductive. Satjipto Rahardjo still recognizes the existence of legal views of social behavior of the law enforcement and the community. The law established is from development in society/starting from the fact that there is in society, this is nondoktrinal-inductive approach. Each law is different depending on the case at hand in accordance with the expression allow the law to flow. Law is defined as a decision of law enforcement. Fundamental law lies not in legal stuff (legal stuff), the legal system, legal thinking, and so on, but rather on humans or human behavior. Based on the behavior of law enforcement and the behavior of the people then normative rule is formed. Laws must be in accordance with the conscience so that it can perform the function of justice that is the result of doctrinal deductive approach of values internalized.

Axiologically, the development legal theory focuses on the legal objectives that are legal certainty and expediency simultaneously. The development legal theory emphasizing the goal of every law is order, which is a fundamental condition for the existence of an ordered society; to achieve the order is needed certainty in relationships between people in society; and the function of the law as a means of renewal of society which can be categorized as expediency.

Progressive legal theory puts more emphasis on the purpose of the law of justice and expediency. Satjipto Raharjo stresses that the application of the progressive legal theory in the transition condition as in Indonesia with the character of the onset of legal issues that overlap each other, full of complications will be required a breakthrough steps in implementing the rule of law so that the function of the law is directed to serve the community $^{21}$.

4. The Table of Analysis of Development Legal Theory and Progressive Legal Theory

In order to further clarify the analysis of both legal theories mentioned above, the following descriptions are presented in the following table.

$+$

\begin{tabular}{|l|l|l|}
\hline & $\begin{array}{l}\text { Development Legal } \\
\text { Theory }\end{array}$ & Progressive Legal Theory \\
\hline
\end{tabular}

\footnotetext{
${ }^{20}$ Shidarta II, Op.Cit, h.505

${ }^{21}$ Bernard L.Tanya, Yoan N.Simanjutak dan Markus Y.Hage, 2013, Teori Hukum Strategi Tertib Manusia Lintas Ruang dan Generasi, Genta Publisihing, Yogyakarta, h.195

DOI: 10.9790/0837-2109026675 $\quad$ www.iosrjournals.org $\quad 72 \mid$ Page
}




\begin{tabular}{|c|c|c|}
\hline Ontological & $\begin{array}{l}\text { Law as a system of } \\
\text { norms (system of norms) } \\
\text { rely on the normative } \\
\text { power that is legislation } \\
\text { to change attitudes and } \\
\text { behavior of society. } \\
\text { Law is one of the social } \\
\text { rules in addition the rule } \\
\text { of religion, morals } \\
\text { The law does not just } \\
\text { rules and principles } \\
\text { governing but also } \\
\text { includes the institutions } \\
\text { and processes necessary } \\
\text { for prevailig the law. The } \\
\text { law } \\
\text { Characterized by } \\
\text { coercion by state. }\end{array}$ & $\begin{array}{l}\text { Law as a behavioral system } \\
\text { (system of behaviour). } \\
\text { The law is Not a final } \\
\text { institution, but is determined } \\
\text { by its ability to serve human. } \\
\text { It is constantly building and } \\
\text { turn itself to the level of } \\
\text { perfection that is better . } \\
\text { Law is allowed to flow. }\end{array}$ \\
\hline Epistemological & $\begin{array}{l}\text { Approach of deductive } \\
\text { doctrinal and inductive } \\
\text { nondoctrinal } \\
\text { simultaneously followed } \\
\text { doctrinal deductive, } \\
\text { meaning the first } \\
\text { approach remains the law } \\
\text { is determined by the } \\
\text { legislative body to be } \\
\text { applied in the } \\
\text { community, and the } \\
\text { results of the evaluation } \\
\text { process (feedback) from } \\
\text { the social reality that } \\
\text { occurs will stimulate new } \\
\text { legislative program, } \\
\text { either the formation of a } \\
\text { new positive norms, the } \\
\text { revocation of positive } \\
\text { norms old, or change }\end{array}$ & $\begin{array}{l}\text { Approach of nondoctrinal- } \\
\text { inductive and doctrinal- } \\
\text { deductive } \\
\text { Nondoctrinal-inductive } \\
\text { approach moved from legal } \\
\text { views of social behavior of } \\
\text { the law enforcement and the } \\
\text { community. } \\
\text { The laws established from } \\
\text { developments in } \\
\text { society/starting from the fact } \\
\text { that there is in the } \\
\text { community. } \\
\text { Each law is different } \\
\text { depending on the case at } \\
\text { hand in accordance with the } \\
\text { expression, allow the law to } \\
\text { flow } \\
\text { Law is defined as a decision } \\
\text { of law enforcement. } \\
\text { Fundamental law lies not in } \\
\text { legal stuff (legal stuff), the } \\
\text { legal system, legal thinking, } \\
\text { and so on, but rather on } \\
\text { humans or human behavior. } \\
\text { Based on the behavior of law } \\
\text { enforcement and } \\
\text { behavior of the people then } \\
\text { normative rule is formed. } \\
\text { Doctrinal-deductive } \\
\text { approach of } \\
\text { internalized. } \\
\text { Laws must be in accordance }\end{array}$ \\
\hline
\end{tabular}




\begin{tabular}{|l|l|l|}
\hline & & $\begin{array}{l}\text { with the conscience so that it } \\
\text { can perform the function of } \\
\text { justice }\end{array}$ \\
\hline Axiological & $\begin{array}{l}\text { Law is established for the } \\
\text { purpose of order } \\
\text { (certainty of law) and } \\
\text { expediency (as a means } \\
\text { of renewing the public to } \\
\text { obtain the goal of } \\
\text { building the aspired) }\end{array}$ & $\begin{array}{l}\text { Law is established for the } \\
\text { purpose of justice and } \\
\text { expediency. }\end{array}$ \\
Law that pro-justice and pro- \\
people. \\
Law is based on conscience.
\end{tabular}

\section{A. CLOSING}

\section{CONCLUSION}

Based on the results of the discussion, then to the two theories revealed by national figures i.e. Mochtar Kusumaatmadja with development legal theory and Satjipto Rahardjo with progressive legal theory, it can be concluded that the essence of thinking, namely:

- Ontologically development legal theory views the law as a system of norms (system of norms) by using the means through legislation as a means for renewal. Epistemologically development legal theory uses doctrinal-deductive approach and indoctrinal-inductive followed by doctrinal-deductive. Axiologically legal is intended for certainty and expediency.

- Ontologically progressive legal theory views the law as a behavioral system (system of behavior). Epistemologically progressive legal theory uses approach of non doctrinal-inductive and doctrinal-deductive. Axiologically law is intended at justice and expediency.

1. Suggestions

To Law enforcers, in order to apply the legal paradigm for people not people for legal so that the function of law is more aimed to justice, in applying that law enforcer can borrow the framework of the two figures of postmodern i.e. Mochtar Kusumaatmadja and Satjipto Rahardjo.

\section{BIBLIOGRAPHY}

[1] Ali, Achmad, 2009, Menguak Teori Hukum (Legal Theory) dan Teori Peradilan (Judicial Prudence) Termasuk Interprestasi Undang-Undang (Legisprudence), Kencana Media Group, Jakarta.

[2] Shidarta, 2006, Karakteristik Penalaran Hukum Dalam Konteks Keindonesiaan, CV.Utomo, Jakarta.

[3] _ 2012, "Posisi Pemikiran Teori Hukum Pembangunan Dalam Konfigurasi Aliran Pemikiran Hukum (Sebuah Diagnosis Awal)" dalam : Shidarta (ed): Mochtar Kusuma-Atmadja dan Teori Hukum Pembangunan Eskistensi dan Implikasi, Epistema Institute, Jakarta.

[4] Tanya, Bernard L, Yoan N.Simanjutak dan Markus Y.Hage, 2013, Teori Hukum Strategi Tertib Manusia Lintas Ruang dan Generasi, Genta Publisihing, Yogyakarta

[5] Rahardjo, Satjipto, 2008, Biarkan Hukum Mengalir Catatan Kritis tentang Pergulatan Manusia dan Hukum, Buku Kompas, Jakarta.

[6] 2009, Hukum Progresif : Sebuah Sintesa Hukum Indonesia, Genta Publishing, Yogyakarta.

[7] Rasjidi, Lili dan I.B. Wyasa Putra, 1993, Hukum sebagai Suatu Sistem, Remaja Rosdakarya, Bandung.

[8] Salman, Otje dan Anthon F.Susanto, 2010, Teori Hukum Mengingat, Mengumpulkan, dan Membuka Kembali, Refika Aditama, Bandung.

\section{Papers}

[9] Kusumaatmadja, Mochtar, 1997, "Pemantapan Cita Hukum dan Asas-Asas Hukum Nasional Di Masa Kini dan Masa Yang Akan Datang”, Majalah Hukum Pro Justitia Nomor 2 Tahun XV, April 1997.

[10] Mulyadi, Lilik, 2008, "Teori Hukum Pembangunan Prof. Dr. Mochtar Kusumaatmadja S.H.,LL.M. Sebuah Kajian Deskriptif Analitis", Artikel, sumber http://www. badilum.info/images/stories/artikel/kajian_deskriptif_analisa_teori_hukum_pembangunan.pdf, diakses pada tanggal 14 Desember 2014. 
[11] Shidarta, Posisi Pemikiran Hukum Progresif Dalam Konfigurasi Aliran-Aliran Filsafat Hukum (Sebuah Diagnosis Awal), sumber http: www.slideshare.net, diakses pada tanggal 14 Desember 2014.

[12] Turiman, 2010, "Memahami Hukum Progresif Prof Satjipto Rahardjo Dalam Paradigma Thawaf (Sebuah Kontemplasi Bagaimana Mewujudkan Teori Hukum Yang Membumi/Grounded Theory MengIndonesia)", Artikel, sumber: www.acadamia.edu, diakses pada tanggal 20 November 2013.

Legislations

[13] Undang-Undang Republik Indonesia Nomor 12 Tahun 2011 Tentang Pembentukan Peraturan Perundangundangan dan Penjelasan Atas Undang-Undang Republik Indonesia Nomor 12 Tahun 2011, Lembaran Negara Republik Indonesia Tahun 2011 Nomor 82 dan Tambahan Lembaran Negara Republik Indonesia Nomor 5234 